\title{
Review Article \\ Nanomedicine for Inner Ear Diseases: A Review of Recent In Vivo Studies
}

\author{
Dong-Kee Kim \\ Department of Otolaryngology-Head and Neck Surgery, Daejeon St. Mary's Hospital, College of Medicine, \\ The Catholic University of Korea, Daejeon, Republic of Korea \\ Correspondence should be addressed to Dong-Kee Kim; cider12@catholic.ac.kr
}

Received 18 July 2017; Accepted 30 August 2017; Published 10 October 2017

Academic Editor: Kenneth H. Lee

Copyright (C) 2017 Dong-Kee Kim. This is an open access article distributed under the Creative Commons Attribution License, which permits unrestricted use, distribution, and reproduction in any medium, provided the original work is properly cited.

\begin{abstract}
Nanoparticles are promising therapeutic options for inner ear disease. In this report, we review in vivo animal studies in the otologic field using nanoparticles over the past 5 years. Many studies have used nanoparticles to deliver drugs, genes, and growth factors, and functional and morphological changes have been observed. The constituents of nanoparticles are also diversifying into various biocompatible materials, including poly(lactic-co-glycolic acid) (PLGA). The safe and effective delivery of drugs or genes in the inner ear will be a breakthrough for the treatment of inner ear diseases, including age-related hearing loss.
\end{abstract}

\section{Introduction}

Hearing loss is a common feature of many inner ear conditions, including presbycusis, sudden sensorineural hearing loss (SSNHL), genetic diseases, noise-induced hearing loss, ototoxic hearing loss, and autoimmune inner ear disease. The prevalence of hearing loss due to these inner ear diseases is increasing because of an increase in life expectancy, exposure to noise, and the use of medicines such as anticancer drugs.

These inner ear diseases remain intractable, and treatment results are poor. One of several reasons for their intractability is that the drug does not readily reach the inner ear. When a drug is administered systemically, it must cross the blood labyrinth barrier (BLB) to reach the inner ear [1]. However, only a small amount of the drug crosses the BLB and reaches the inner ear. Therefore, high doses of medication must be administered to achieve the appropriate drug concentration in the inner ear and have a therapeutic effect. However, systemic administration of high drug concentrations, particularly steroids, has numerous side effects.

Intratympanic drug injection has been used to address these problems and has become the standard treatment for Meniere's disease and sudden deafness [2, 3]. In some ways, the inner ear is well suited to local delivery of drugs. Local delivery bypasses the BLB, allowing drugs to reach their intended target at a lower dose. Thus, higher drug concentrations can be achieved while systemic effects are minimized. However, the drug concentration in the inner ear obtained through intratympanic drug injection remains low.

Several methods have been proposed to improve the efficiency of intratympanic drug injection, such as use of the Silverstein Microwick (Micromedics, St. Paul, MN), microcatheter implantation, hydrogels, and nanoparticles [4]. In this report, we focus on in vivo studies in the otologic field using nanoparticles within the past 5 years. In theory, nanoparticle-based drug delivery can enhance the efficiency of delivery to the inner ear and release drugs in a sustained manner [5]. Nanoparticles also provide physical protection in vivo for delicate drug structures [6].

\section{Challenges with Inner Ear Drug Delivery}

The first challenge is ensuring the safety of the drug carrier in the middle or inner ear [7]. Nanoparticles have been used extensively in cancer therapy where cell viability is not an important issue; however, safety is an absolute requirement for nanoparticle applications for the treatment of deafness. To increase permeability into cells or to perform gene transfer, a positively charged moiety such as a cell-penetrating peptide can be attached to the nanoparticle $[8,9]$. However, because positively charged nanoparticles can be ototoxic through limited biodegradability of the particle, the production of 
intracellular reactive oxygen species, and damage of cell membranes, their application to hearing loss is limited [10]. In addition, it must be determined whether the constituent materials of the nanoparticles will accumulate in the inner ear and be cleared or remain in the inner ear and whether these materials are toxic to hair cells.

When a drug is administered to the middle ear through intratympanic drug injection, it must pass the round window membrane (RWM) or the annular ligament of the oval window $(\mathrm{OW})$ to reach the inner ear. It remains unclear whether these two windows are crossed through diffusion or endocytosis [11]. However, the drug must remain in the middle ear cavity for a sufficient amount of time and remain in contact with these two windows to be delivered to the inner ear. Unfortunately, drugs that enter the middle ear cavity do not remain and are quickly discharged to the Eustachian tube through mucociliary flow of the middle ear [12]. In response to this, gels have been studied in many animal studies. Other studies have used thermosensitive gels, which exist in a liquid state at room temperature and a gel state at body temperature [13].

Another challenge with intratympanic drug delivery is the low permeability of the RWM and annular ligament of the OW. Although the dominant entry route for the inner ear remains unknown, the RWM seems to be the dominant route. Salt et al. [14] reported distribution of an ionic marker, trimethylphenylammonium (TMPA), in the cochlea after intracochlear injection or application to the round window niche based on direct monitoring using a TMPA selective electrode or sequential collection of perilymph. A total of $65 \%$ of TMPA entered through the RWM while 35\% entered the vestibule in the vicinity of the stapes. However, in clinical situations, RWM may be blocked by fat or fiber tissue; fat or fiber tissue can interfere with drug delivery through the RWM [15]. Factors such as size, configuration, concentration, liposolubility, electrical charge, and membrane thickness influence permeability [16]. Smaller agents are transported more readily through the RWM. Zou et al. [17] explored sizedependent nanoparticle transport. Three sizes of liposome nanoparticles $(95,130$, and $240 \mathrm{~nm})$ were manufactured, and their distribution was measured after transtympanic injection in rats. The $95 \mathrm{~nm}$ particles were transported most easily whereas the $240 \mathrm{~nm}$ particles were transported least easily. With regard to charge, in rodents cationic ferritin readily passes through the normal RWM, whereas anionic ferritin does not $[16,18]$.

\section{Studies Investigating the Uptake or Toxicity of Nanoparticles in the Inner Ear}

Wen et al. [19] explored several surface-modified PLGA nanoparticles for inner ear drug delivery, of which poloxamer 407-PLGA nanoparticles showed the greatest cellular uptake and strongest fluorescence based on cochlear imaging. It is possible to analyze quantitatively the amount of nanoparticle entering the cochlea using a near-infrared fluorescence imaging system after cochlea harvest (Table 1). However, a more physiological and accurate method would be to analyze quantitatively the cochlea in a live state. This may be accomplished by isolating the perilymph and determining the concentration of the drug using HPLC. However, it is difficult to quantify drug absorbed in cells of the inner ear (not the perilymph) using this method.

In addition, inner ear drug delivery studies using superparamagnetic nanoparticles and chitosan hydrogel-based nanoparticles have recently been published, and both showed good safety and drug delivery efficiency [20, 21] (Table 1).

\section{Studies Attempting to Deliver Actual Drugs to the Inner Ear Using Nanoparticles}

In recent years, rather than simply investigating the permeation of nanoparticles into the inner ear, a growing number of reports have loaded a drug onto the nanoparticle and transferred it to the inner ear to observe functional changes (Table 2).

Drug delivery using polyethylene glycol-coated polylactic acid (PEG-PLA) nanoparticles has been attempted twice by the same group $[22,23]$. This group used cisplatin to deafen guinea pigs after pretreatment systemically or intratympanically with dexamethasone-loaded nanoparticles. In both studies, administration of dexamethasone-loaded nanoparticles protected hearing in the $4 \mathrm{kHz}$ and $8 \mathrm{kHz}$ frequencies. In another study in which $6 \alpha$-methylprednisolone was loaded onto nanoparticles using alpha-tocopherol derivatives, cisplatin-induced hearing loss was protected at 10, 14, and $16 \mathrm{kHz}$ [24].

Other reports (excluding the aforementioned studies) have not evaluated changes in hearing after the administration of nanoparticles but instead have analyzed quantitatively the concentration of drug delivered to the inner ear based on high-performance liquid chromatography (HPLC) or fluorescence spectrophotometry [25-28]. One interesting study proposed intratympanic drug injection as a potential brain drug delivery route by analyzing the drug concentration in brain tissue and cerebrospinal fluid (CSF) after intratympanic drug administration [26]. Multiple agentloaded nanoparticles following intratympanic injection in guinea pigs significantly improved drug distribution within the inner ear, CSF, and brain tissues and protected the brain from cerebral ischemia reperfusion injury.

\section{Studies Attempting to Deliver Growth Factors to the Inner Ear Using Nanoparticles}

The delivery of macromolecules including growth factors to the inner ear may be more clinically useful than simple drug delivery. This is because in individuals with chronic hearing loss, hair cells cannot be regenerated through drug delivery, although they may be facilitated by the delivery of growth factors or genes. Brain-derived neurotrophic factor (BDNF) has been investigated in many animal studies and can preserve the population of spiral ganglion neurons after hair cell loss [37, 38]. It is also considered a candidate growth factor for reversing hearing loss [39]. 
TABLE 1: Studies investigating the uptake or toxicity of nanoparticles in the inner ear.

\begin{tabular}{|c|c|c|c|c|c|c|}
\hline Nanoparticle & $\begin{array}{c}\text { Size of } \\
\text { nanoparticle }\end{array}$ & Animal & $\begin{array}{l}\text { Administration } \\
\text { route }\end{array}$ & $\begin{array}{l}\text { Loaded drug or } \\
\text { gene }\end{array}$ & Evaluation time & $\begin{array}{c}\text { Evaluation of } \\
\text { nanoparticle uptake }\end{array}$ \\
\hline $\begin{array}{l}\text { Poloxamer 407-PLGA } \\
\text { NP [19] }\end{array}$ & $181.5 \mathrm{~nm}$ & Guinea pigs & Intratympanic & DiR & At $24 \mathrm{~h}$ & $\begin{array}{c}\text { Near-infrared } \\
\text { fluorescence imaging } \\
\text { system, confocal } \\
\text { microscope }\end{array}$ \\
\hline $\begin{array}{l}\text { Superparamagnetic } \\
\mathrm{NP}[20]\end{array}$ & $\begin{array}{l}\text { 100, 200, and } \\
500 \text { nm (three } \\
\text { kinds) }\end{array}$ & Guinea pigs & Intracochlear & None & At 7 days & $\begin{array}{l}\text { Toxicity evaluation by } \\
\text { ABR }\end{array}$ \\
\hline $\begin{array}{l}\text { Chitosan-hydrogel- } \\
\text { based NP } \\
{[21]} \\
\end{array}$ & $160 \mathrm{~nm}$ & C57BL/6J mice & Intratympanic & Fluorescent dye & At $24 \mathrm{~h}$ & $\begin{array}{l}\text { Fluorescent } \\
\text { microscopy }\end{array}$ \\
\hline
\end{tabular}

TABLE 2: Studies attempting to deliver actual drugs to the inner ear using nanoparticles.

\begin{tabular}{|c|c|c|c|c|c|c|}
\hline Nanoparticle & $\begin{array}{c}\text { Size of } \\
\text { nanoparticle }\end{array}$ & Animal & $\begin{array}{l}\text { Administration } \\
\text { route }\end{array}$ & Loaded drug or gene & Evaluation time & $\begin{array}{c}\text { Evaluation of } \\
\text { nanoparticle } \\
\text { uptake }\end{array}$ \\
\hline $\begin{array}{l}\text { PEG-PLA NP } \\
{[22]}\end{array}$ & Not described & $\begin{array}{c}\text { Guinea pig, } \\
\text { deafened with } \\
\text { cisplatin }\end{array}$ & Intraperitoneal & Dexamethasone & At 3 days & $\begin{array}{l}\text { ABR and } \\
\text { morphology }\end{array}$ \\
\hline $\begin{array}{l}\text { PEG-PLA NP } \\
{[23]}\end{array}$ & $130 \pm 4.78 \mathrm{~nm}$ & $\begin{array}{c}\text { Guinea pig, } \\
\text { deafened with } \\
\text { cisplatin }\end{array}$ & Intratympanic & Dexamethasone & At 3 days & $\begin{array}{l}\text { ABR and } \\
\text { morphology }\end{array}$ \\
\hline $\begin{array}{l}\text { Multimicellar } \\
\text { NP [24] }\end{array}$ & $120.8 \sim 159.9 \mathrm{~nm}$ & $\begin{array}{c}\text { Wistar rats, } \\
\text { deafened with } \\
\text { cisplatin }\end{array}$ & Intratympanic & $\begin{array}{c}6 \alpha- \\
\text { methylprednisolone }\end{array}$ & At 3 days & ASSR \\
\hline PLGA NP [25] & $\begin{array}{l}135 \mathrm{~nm} \text { with a } \\
\text { PDI of } 0.17\end{array}$ & Guinea pigs & Intratympanic & $\begin{array}{l}\text { Salvianolic acid B, } \\
\text { tanshinone IIA, and } \\
\text { total panax } \\
\text { notoginsenoside }\end{array}$ & $\begin{array}{c}\text { At several } \\
\text { predetermined } \\
\text { time points } \\
\text { within } 96 \mathrm{~h} \\
\end{array}$ & $\begin{array}{l}\text { HPLC of } \\
\text { perilymph }\end{array}$ \\
\hline PLGA NP [26] & $\begin{array}{l}154 \mathrm{~nm} \text { with } \\
\text { PDI } 0.007\end{array}$ & Guinea pigs & Intratympanic & $\begin{array}{l}\text { Salvianolic acid B, } \\
\text { tanshinone IIA, and } \\
\text { total panax } \\
\text { notoginsenoside }\end{array}$ & $\begin{array}{l}\text { At several } \\
\text { predetermined } \\
\text { time points } \\
\text { within } 36 \mathrm{~h}\end{array}$ & $\begin{array}{l}\text { HPLC of blood, } \\
\text { perilymph, CSF, } \\
\text { and brain tissue }\end{array}$ \\
\hline $\begin{array}{l}\text { PLGA- } \\
\text { magnetite-NP } \\
{[27]}\end{array}$ & $482.8 \pm 158 \mathrm{~nm}$ & Guinea pigs & Intratympanic & $\begin{array}{c}\text { Dexamethasone } \\
\text { acetate }\end{array}$ & At $30 \mathrm{~min}$ & $\begin{array}{c}\text { HPLC of } \\
\text { perilymph, RWM, } \\
\text { and inner ear tissue }\end{array}$ \\
\hline $\begin{array}{l}\text { Cubic liquid } \\
\text { crystalline NP } \\
{[28]}\end{array}$ & $138.6 \sim 210.9 \mathrm{~nm}$ & Guinea pigs & Intratympanic & $\begin{array}{l}\text { Earthworm } \\
\text { fibrinolytic enzyme }\end{array}$ & $\begin{array}{l}\text { At several } \\
\text { predetermined } \\
\text { time points } \\
\text { within } 24 \mathrm{~h}\end{array}$ & $\begin{array}{c}\text { Fluorescence } \\
\text { microscope and } \\
\text { spectrophotometer }\end{array}$ \\
\hline
\end{tabular}

NP: nanoparticle; ABR: auditory brainstem response; PEG-PLA: polyethylene glycol-coated polylactic acid; ASSR: auditory steady-state responses; RWM: round window membrane.

Recently, several studies have explored the ability of BDNF and NGF to deliver growth factors to the inner ear; however, many of these studies used intracochlear delivery [29-32] (Table 3). Because intracochlear delivery requires surgery and can lead to the loss of remnant hearing by opening the cochlea, it can only be attempted in completely deaf patients, such as for cochlear implant surgery. Intratympanic delivery is more useful because of easy clinical access. However, delivering a large macromolecule such as a growth factor remains challenging.

\section{Studies Attempting to Deliver Genes to the Inner Ear Using Nanoparticles}

A safe and useful nonviral gene delivery system has very high clinical value and can be used to deliver genes to patients with congenital or chronic hearing loss. For example, genes such as Atohl can potentially regenerate hair cells in patients with chronic hearing loss, such as presbycusis.

Two recent studies have attempted gene transfer using GFP fluorescence as a positive transfer marker $[8,33]$ 
TABLE 3: Studies attempting to deliver growth factors to the inner ear using nanoparticles.

\begin{tabular}{|c|c|c|c|c|c|c|}
\hline Nanoparticle & $\begin{array}{c}\text { Size of } \\
\text { nanoparticle }\end{array}$ & Animal & $\begin{array}{l}\text { Administration } \\
\text { route }\end{array}$ & $\begin{array}{l}\text { Loaded drug or } \\
\text { gene }\end{array}$ & Evaluation time & $\begin{array}{c}\text { Evaluation of } \\
\text { nanoparticle } \\
\text { uptake }\end{array}$ \\
\hline $\begin{array}{l}\text { Silica supraparticle } \\
{[29,30]}\end{array}$ & $\begin{array}{c}500 \mu \mathrm{m} \text { (porous } \\
\text { structure) }\end{array}$ & $\begin{array}{c}\text { Deafened guinea } \\
\text { pigs }\end{array}$ & Intracochlear & BDNF & At 4 weeks & Survival of SGNs \\
\hline $\begin{array}{l}\text { Phytantriol } \\
\text { lipid-based } \\
\text { crystalline NP [31] }\end{array}$ & $215.6 \sim 227.2 \mathrm{~nm}$ & $\begin{array}{l}\text { Guinea pigs, } \\
\text { deafened with } \\
\text { cisplatin }\end{array}$ & Intratympanic & NGF & $\begin{array}{c}\text { At several } \\
\text { predetermined } \\
\text { time points within } \\
24 \mathrm{~h}\end{array}$ & $\begin{array}{l}\text { ELISA assay of } \\
\text { cochlear fluid }\end{array}$ \\
\hline $\begin{array}{l}\text { Nanoporous PGA } \\
\text { NP [32] }\end{array}$ & $1.8-3.2 \mu \mathrm{m}$ & $\begin{array}{c}\text { Guinea pig, } \\
\text { deafened with } \\
\text { aminoglycoside } \\
\end{array}$ & Intracochlear & $\mathrm{BDNF}$ & At 20 days & Morphology \\
\hline
\end{tabular}

BDNF: brain-derived neurotrophic factor; SGN: spiral ganglion neurons; NP: nanoparticle; NGF: nerve growth factor; PGA: poly(L-glutamic acid).

TABLE 4: Studies attempting to deliver genes to the inner ear using nanoparticles.

\begin{tabular}{|c|c|c|c|c|c|c|}
\hline Nanoparticle & $\begin{array}{c}\text { Size of } \\
\text { nanoparticle }\end{array}$ & Animal & $\begin{array}{l}\text { Administration } \\
\text { route }\end{array}$ & $\begin{array}{l}\text { Loaded drug } \\
\text { or gene }\end{array}$ & Evaluation time & $\begin{array}{c}\text { Evaluation of } \\
\text { nanoparticle } \\
\text { uptake }\end{array}$ \\
\hline PHEA NP [16] & $103.1 \mathrm{~nm}$ & C57/BL6 mice & Intratympanic & $\begin{array}{c}\text { GFP plasmid } \\
\text { DNA and } \\
\text { fluorescent } \\
\text { dye }\end{array}$ & At $48 \mathrm{~h}$ & $\begin{array}{l}\text { Confocal } \\
\text { microscope }\end{array}$ \\
\hline $\begin{array}{l}\text { Dendrimer-based NP } \\
\text { [33] }\end{array}$ & $132 \pm 20 \mathrm{~nm}$ & $\begin{array}{l}\text { Sprague Dawley } \\
\text { rats }\end{array}$ & Intratympanic & $\begin{array}{l}\text { Atohl-EGFP } \\
\text { plasmid }\end{array}$ & At 7 days & $\begin{array}{c}\text { Confocal } \\
\text { microscope, } \\
\text { RT-PCR, and } \\
\text { Western blot }\end{array}$ \\
\hline
\end{tabular}

NP: nanoparticle; PHEA: poly(2-hydroxyethyl L-aspartamide).

(Table 4). However, it remains difficult to analyze quantitatively the amount of gene delivered to the inner ear using this method because of autofluorescence of the inner ear and the vulnerability of fluorescence intensity to the laser of a confocal microscope. In one of these studies, pRK5Atohl-EGFP plasmids were transferred and gene transfer was analyzed quantitatively based on RT-PCR and Western blot, which appeared to be a reliable approach [33]. Although this report did not assess structural or functional changes after atohl delivery, these results demonstrate the possibility of the possibility of nonviral gene delivery through nanoparticles.

Several challenges with gene delivery using nanoparticles must be addressed before it can be applied clinically, such as decreasing the particle size while stably integrating the gene into the particle; administering a gene and nanoparticle complex to the body; protecting the gene from degrading enzymes such as endonuclease; and ensuring that the gene enters the cytoplasm, escapes the endosome, and enters the nucleus.

\section{Inner Ear Drug Delivery Studies with Imaging Modalities}

Direct observation of drugs or nanoparticles in the inner ear with micro-CT or MRI can be used for quantitative analysis of the amount or distribution of a drug delivered to the cochlea. Zou et al. [34] recently injected silver nanoparticles (Ag NPs) intratympanically and observed the distribution of Ag NPs in the middle and inner ear using micro-CT, showing a gradient concentration from the middle ear to the inner ear (Table 5).

It is possible to detect the distribution of nanoparticles within the inner ear using MRI if the nanoparticles contain paramagnetic agents such as gadolinium chelate [40]. In a recent study, gadolinium chelate was encapsulated in a liposome nanocarrier and the distribution of nanoparticles in the inner ear after intratympanic injection was observed using MRI [35]. In addition to nanoparticles containing gadolinium, superparamagnetic iron oxide nanoparticles (SPION) or ceric ammonium nitrate oxidantstabilized gamma-maghemite nanoparticles were identified in the inner ear using MRI after intratympanic or intracochlear administration [36, 41].

\section{Conclusion}

The use of nanoparticles is a promising therapy for inner ear disease. The ideal nanocarrier should be able to permeate the RWM or the annular ligament on the OW, be capable of specific targeting, provide controlled release of the loaded materials, and be safe in the inner ear. Many studies have attempted to deliver drugs, genes, and growth factors to the inner ear in vivo, and promising results have been reported. The safe and effective delivery of drugs or genes will be an important advancement for the treatment of many inner 
TABLE 5: Inner ear drug delivery studies with imaging modalities.

\begin{tabular}{|c|c|c|c|c|c|c|}
\hline Nanoparticle & $\begin{array}{c}\text { Size of } \\
\text { nanoparticle }\end{array}$ & Animal & $\begin{array}{l}\text { Administration } \\
\text { route }\end{array}$ & $\begin{array}{l}\text { Loaded drug or } \\
\text { gene }\end{array}$ & Evaluation time & $\begin{array}{c}\text { Evaluation of } \\
\text { nanoparticle } \\
\text { uptake } \\
\end{array}$ \\
\hline Silver NP [34] & $21 \pm 8 \mathrm{~nm}$ & $\begin{array}{c}\text { Sprague Dawley } \\
\text { rats } \\
\end{array}$ & Intratympanic & None & $\begin{array}{l}\text { At } 4,7 \text {, and } 24 \mathrm{~h} \\
\text { and at } 7 \text { days }\end{array}$ & Micro-CT \\
\hline $\begin{array}{l}\text { Liposome nanocarrier } \\
\text { [35] }\end{array}$ & $115 \pm 10 \mathrm{~nm}$ & $\begin{array}{l}\text { Sprague Dawley } \\
\text { rats }\end{array}$ & Intratympanic & Gd-DOTA & $\begin{array}{c}\text { At several } \\
\text { predetermined } \\
\text { time points within } \\
7 \text { days }\end{array}$ & $\begin{array}{c}\text { MRI, ABR, and } \\
\text { inflammatory } \\
\text { biological markers }\end{array}$ \\
\hline $\begin{array}{l}\text { Ceric ammonium nitrate } \\
\text { oxidant-stabilized } \\
\text { gamma-maghemite NP } \\
\text { [36] }\end{array}$ & $50-60 \mathrm{~nm}$ & $\begin{array}{l}\text { Sprague Dawley } \\
\text { rats }\end{array}$ & Intratympanic & None & $\begin{array}{c}\text { At several } \\
\text { predetermined } \\
\text { time points within } \\
14 \text { days }\end{array}$ & MRI \\
\hline
\end{tabular}

NP: nanoparticle; Gd-DOTA: gadolinium-tetra-azacyclo-dodecane-tetra-acetic acid; ABR: auditory brainstem response.

ear diseases, including age-related hearing loss, which is currently a refractory disease.

\section{Disclosure}

The English in this document has been checked by at least two professional editors, both native speakers of English. For a certificate, please see http://www.textcheck.com/certificate/ lbQYk7.

\section{Conflicts of Interest}

The author declares that there are no conflicts of interest regarding the publication of this paper.

\section{Acknowledgments}

This research was supported by the Basic Science Research Program through the National Research Foundation of Korea (NRF) and funded by the Ministry of Education (NRF2017R1D1A1B03027894) and the Catholic Medical Center Research Foundation in program year 2017.

\section{References}

[1] S. K. Juhn, L. P. Rybak, and W. L. Fowlks, "Transport characteristics of the blood-Perilymph barrier," American Journal of Otolaryngology-Head and Neck Medicine and Surgery, vol. 3, no. 6, pp. 392-396, 1982.

[2] H. Sajjadi and M. M. Paparella, "Meniere's disease," The Lancet, vol. 372, no. 9636, pp. 406-414, 2008.

[3] W. H. Slattery, L. M. Fisher, Z. Iqbal, R. A. Friedman, and N. Liu, "Intratympanic steroid injection for treatment of idiopathic sudden hearing loss," Otolaryngology - Head and Neck Surgery, vol. 133, no. 2, pp. 251-259, 2005.

[4] A. A. McCall, E. E. L. Swan, J. T. Borenstein, W. F. Sewell, S. G. Kujawa, and M. J. McKenna, "Drug delivery for treatment of inner ear disease: current state of knowledge," Ear and Hearing, vol. 31, no. 2, pp. 156-165, 2010.

[5] I. Pyykko, J. Zou, W. Zhang, and Y. Zhang, "Nanoparticlebased delivery for the treatment of inner ear disorders," Current
Opinion in Otolaryngology \& Head and Neck Surgery, vol. 19, no. 5, pp. 388-396, 2011.

[6] M. Yokoyama, M. Miyauchi, N. Yamada et al., "Characterization and Anticancer Activity of the Micelle-forming Polymeric Anticancer Drug Adriamycin-conjugated Poly(ethylene glycol)Poly(aspartic acid) Block Copolymer," Cancer Research, vol. 50, no. 6, pp. 1693-1700, 1990.

[7] J. Zou, H. Feng, M. Mannerström, T. Heinonen, and I. Pyykkö, "Toxicity of silver nanoparticle in rat ear and BALB/c 3T3 cell line," Journal of Nanobiotechnology, vol. 12, no. 1, article no. 52, 2014.

[8] J. Y. Yoon, K.-J. Yang, D. E. Kim et al., "Intratympanic delivery of oligoarginine-conjugated nanoparticles as a gene (or drug) carrier to the inner ear," Biomaterials, vol. 73, pp. 243-253, 2015.

[9] R. Y. Seung, B. K. Seung, C. O. Joe, and J.-D. Kim, "Intracellular delivery enhancement of poly(amino acid) drug carriers by oligoarginine conjugation," Journal of Biomedical Materials Research - Part A, vol. 86, no. 1, pp. 137-148, 2008.

[10] H. Zhou, X. Ma, Y. Liu et al., "Linear polyethylenimineplasmid DNA nanoparticles are ototoxic to the cultured sensory epithelium of neonatal mice," Molecular Medicine Reports, vol. 11, no. 6, pp. 4381-4388, 2015.

[11] M. V. Goycoolea, "Clinical aspects of round window membrane permeability under normal and pathological conditions," Acta Oto-Laryngologica, vol. 121, no. 4, pp. 437-447, 2001.

[12] J. Sadé, "Mucociliary flow in the middle ear," Annals of Otology, Rhinology \& Laryngology, vol. 80, no. 3, pp. 336-341, 1971.

[13] A. N. Salt, J. Hartsock, S. Plontke, C. LeBel, and F. Piu, "Distribution of dexamethasone and preservation of inner ear function following intratympanic delivery of a gel-based formulation," Audiology \& Neuro-otology, vol. 16, no. 5, pp. 323$335,2011$.

[14] A. N. Salt, E. B. King, J. J. Hartsock, R. M. Gill, and S. J. O’Leary, "Marker entry into vestibular perilymph via the stapes following applications to the round window niche of guinea pigs," Hearing Research, vol. 283, no. 1-2, pp. 14-23, 2012.

[15] K. S. Alzamil and F. H. Linthicum Jr., "Extraneous round window membranes and plugs: Possible effect on intratympanic therapy," Annals of Otology, Rhinology and Laryngology, vol. 109, no. 1, pp. 30-32, 2000.

[16] M. V. Goycoolea, D. Muchow, and P. Schachern, "Experimental studies on round window structure: Function and permeability," The Laryngoscope, vol. 98, no. S44, pp. 1-20, 1988. 
[17] J. Zou, R. Sood, S. Ranjan et al., "Size-dependent passage of liposome nanocarriers with preserved posttransport integrity across the middle-inner ear barriers in rats. Otology Neurotology: Official Publication of the American Otological Society," Otology \& Neurotology: Official Publication of the American Otological Society, American Neurotology Society [and] European Academy of Otology and Neurotology, vol. 33, no. 4, pp. 666-673, 2012.

[18] Y. Nomura, "Otological significance of the round window," Advances in oto-rhino-laryngology, vol. 33, pp. 1-162, 1984.

[19] X. Wen, S. Ding, H. Cai et al., "Nanomedicine strategy for optimizing delivery to outer hair cells by surface-modified poly(lactic/glycolic acid) nanoparticles with hydrophilic molecules," International Journal of Nanomedicine, vol. 11, pp. 5959-5969, 2016.

[20] Y. Nguyen, C. Celerier, R. Pszczolinski et al., "Superparamagnetic nanoparticles as vectors for inner ear treatments: Driving and toxicity evaluation," Acta Oto-Laryngologica, vol. 136, no. 4, pp. 402-408, 2016.

[21] S. A. Lajud, D. A. Nagda, P. Qiao et al., "A novel chitosanhydrogel-based nanoparticle delivery system for local inner ear application," Otology \& Neurotology: Official Publication of the American Otological Society, American Neurotology Society [and] European Academy of Otology and Neurotology, vol. 36, no. 2, pp. 341-347, 2015.

[22] C. Sun, X. Wang, D. Chen, X. Lin, D. Yu, and H. Wu, "Dexamethasone loaded nanoparticles exert protective effects against Cisplatin-induced hearing loss by systemic administration," Neuroscience Letters, vol. 619, pp. 142-148, 2016.

[23] C. Sun, X. Wang, Z. Zheng et al., "A single dose of dexamethasone encapsulated in polyethylene glycol-coated polylactic acid nanoparticles attenuates cisplatin-induced hearing loss following round window membrane administration," International Journal of Nanomedicine, vol. 10, pp. 3567-3579, 2015.

[24] S. Martín-Saldaña, R. Palao-Suay, A. Trinidad, M. R. Aguilar, R. Ramírez-Camacho, and J. San Román, "Otoprotective properties of $6 \alpha$-methylprednisolone-loaded nanoparticles against cisplatin: In vitro and in vivo correlation," Nanomedicine: Nanotechnology, Biology, and Medicine, vol. 12, no. 4, pp. 965976, 2016.

[25] H. Cai, X. Wen, L. Wen et al., "Enhanced local bioavailability of single or compound drugs delivery to the inner ear through application of PLGA nanoparticles via round window administration," International Journal of Nanomedicine, p. 5591.

[26] X. Zhang, G. Chen, and L. Wen, "Novel multiple agents loaded PLGA nanoparticles for brain delivery via inner ear administration: in vitro and in vivo evaluation," European Journal of Pharmaceutical Sciences, vol. 48, no. 4-5, pp. 595-603, 2013.

[27] X. Du, K. Chen, S. Kuriyavar et al., "Magnetic targeted delivery of dexamethasone acetate across the round window membrane in guinea pigs," Otology \& Neurotology: Official Publication of the American Otological Society, American Neurotology Society [and] European Academy of Otology and Neurotology, vol. 34, no. 1, pp. 41-47, 2013.

[28] H. Liu, Y. Wang, Q. Wang et al., "Protein-bearing cubosomes prepared by liquid precursor dilution: Inner ear delivery and pharmacokinetic study following intratympanic administration," Journal of Biomedical Nanotechnology, vol. 9, no. 10, pp. 1784-1793, 2013.
[29] A. K. Wise, J. Tan, Y. Wang, F. Caruso, and R. K. Shepherd, "Improved auditory nerve survival with nanoengineered supraparticles for neurotrophin delivery into the deafened cochlea," PLoS ONE, vol. 11, no. 10, Article ID e0164867, 2016.

[30] Y. Wang, A. K. Wise, J. Tan, J. W. Maina, R. K. Shepherd, and F. Caruso, "Mesoporous silica supraparticles for sustained innerear drug delivery," Small, vol. 10, no. 21, pp. 4244-4248, 2014.

[31] M. Bu, J. Tang, Y. Wei et al., "Enhanced bioavailability of nerve growth factor with phytantriol lipid-based crystalline nanoparticles in cochlea," International Journal of Nanomedicine, vol. 10, pp. 6879-6889, 2015.

[32] J. Tan, Y. Wang, X. Yip, F. Glynn, R. K. Shepherd, and F. Caruso, "Nanoporous peptide particles for encapsulating and releasing neurotrophic factors in an animal model of neurodegeneration," Advanced Materials, vol. 24, no. 25, pp. 3362-3366, 2012.

[33] N. Wu, M. Li, Z.-T. Chen et al., "In vivo delivery of Atohl gene to rat cochlea using a dendrimer-based nanocarrier," Journal of Biomedical Nanotechnology, vol. 9, no. 10, pp. 1736-1745, 2013.

[34] J. Zou, M. Hannula, S. Misra et al., "Micro CT visualization of silver nanoparticles in the middle and inner ear of rat and transportation pathway after transtympanic injection," Journal of Nanobiotechnology, vol. 13, no. 1, article no. 5, 2015.

[35] J. Zou, H. Feng, R. Sood, P. K. Kinnunen, and I. Pyykko, "Biocompatibility of Liposome Nanocarriers in the Rat Inner Ear After Intratympanic Administration," Nanoscale Research Letters, vol. 12, no. 1, 2017.

[36] J. Zou, S. Ostrovsky, L. L. Israel et al., "Efficient penetration of ceric ammonium nitrate oxidant-stabilized gamma-maghemite nanoparticles through the oval and round windows into the rat inner ear as demonstrated by MRI," Journal of Biomedical Materials Research - Part B Applied Biomaterials, 2016.

[37] R. T. Richardson, A. K. Wise, B. C. Thompson et al., "Polypyrrole-coated electrodes for the delivery of charge and neurotrophins to cochlear neurons," Biomaterials, vol. 30, no. 13, pp. 2614-2624, 2009.

[38] D. Ramekers, H. Versnel, S. B. Strahl, S. F. L. Klis, and W. Grolman, "Temporary neurotrophin treatment prevents deafnessinduced auditory nerve degeneration and preserves function," Journal of Neuroscience, vol. 35, no. 36, pp. 12331-12345, 2015.

[39] I. Khalin, R. Alyautdin, G. Kocherga, and M. A. Bakar, "Targeted delivery of brain-derived neurotrophic factor for the treatment of blindness and deafness," International Journal of Nanomedicine, vol. 10, pp. 3245-3267, 2015.

[40] I. Pyykkö, J. Zou, A. Schrott-Fischer, R. Glueckert, and P. Kinnunen, "An overview of nanoparticle based delivery for treatment of inner ear disorders," Methods in Molecular Biology, vol. 1427, pp. 363-415, 2016.

[41] J. Zou, W. Zhang, D. Poe et al., "MRI manifestation of novel superparamagnetic iron oxide nanoparticles in the rat inner ear," Nanomedicine, vol. 5, no. 5, pp. 739-754, 2010. 

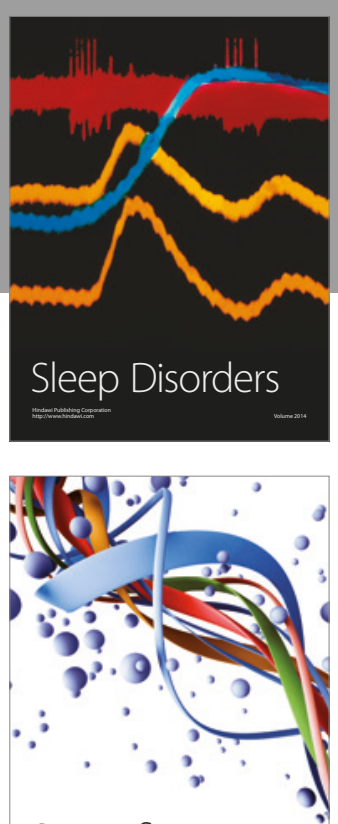

Scientifica
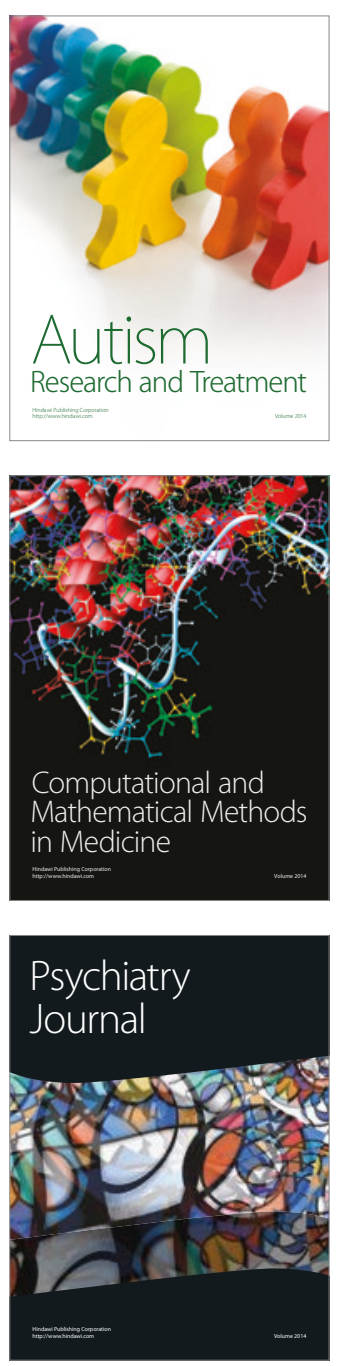
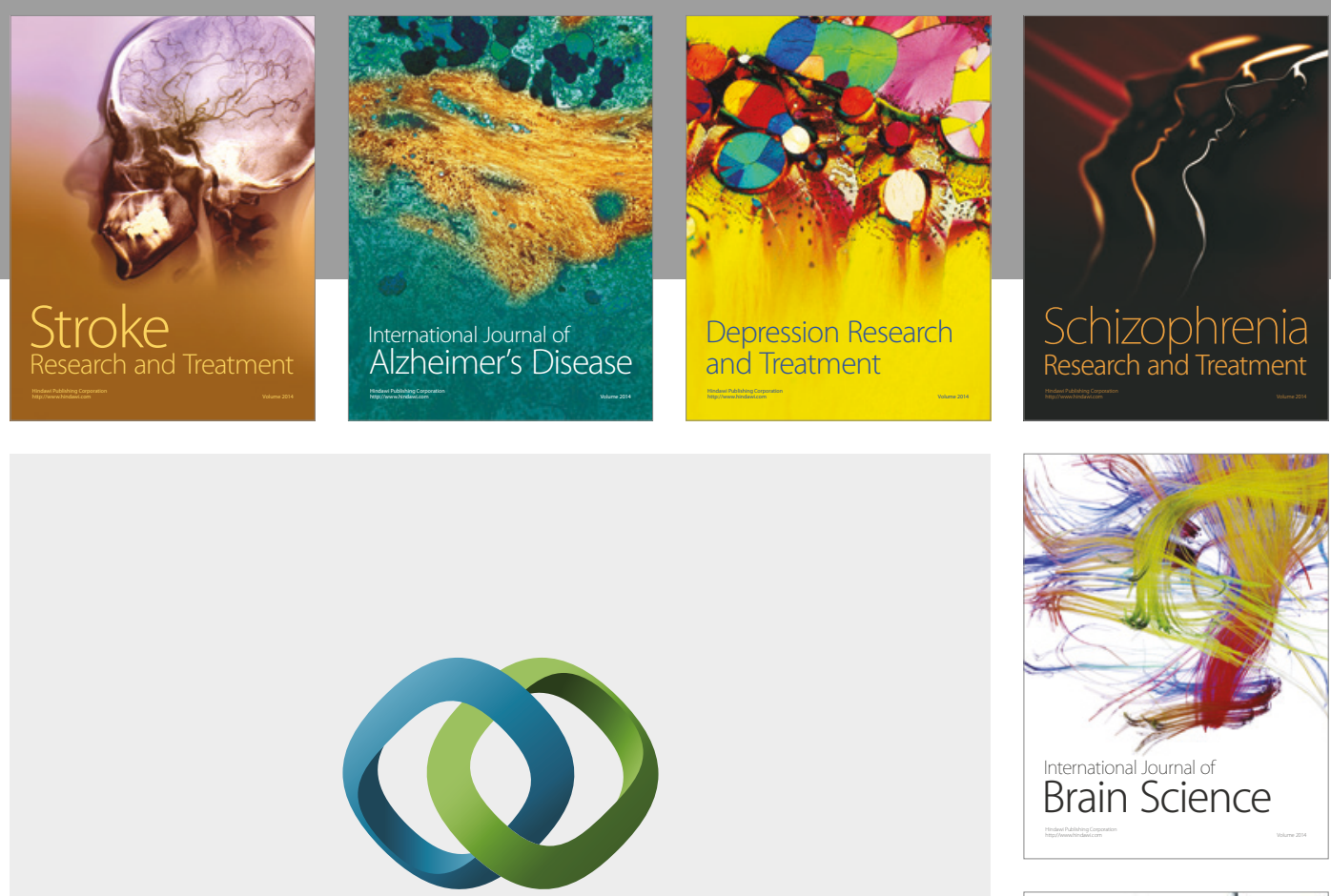

\section{Hindawi}

Submit your manuscripts at

https://www.hindawi.com
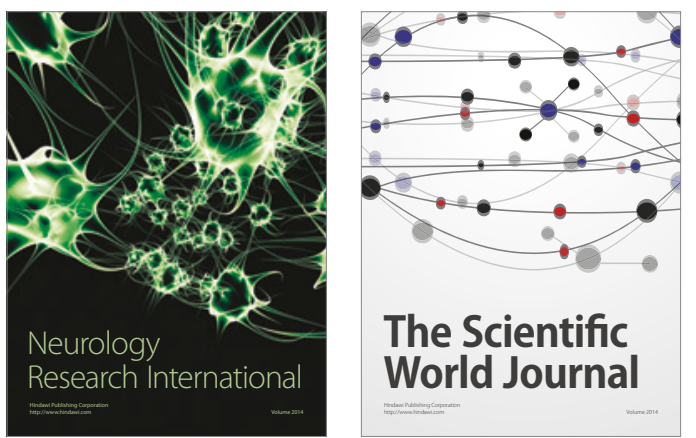

The Scientific World Journal

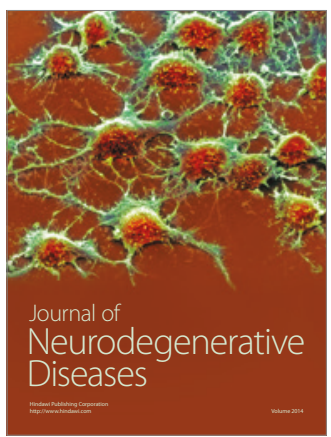

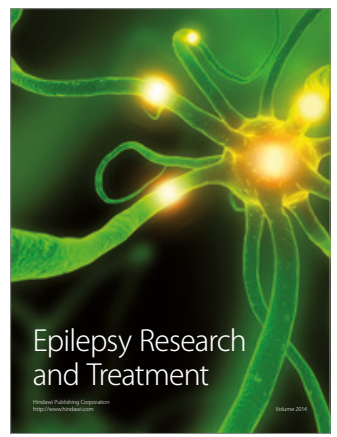

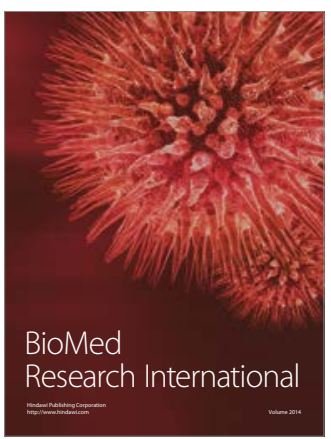

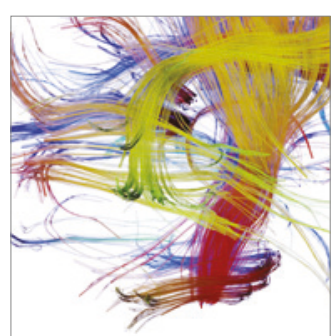

Brain Science

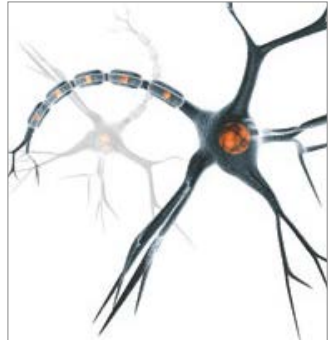

Neural Plasticity
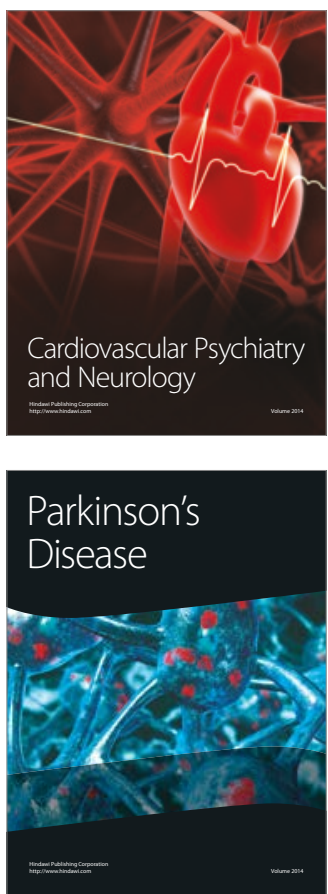